\title{
Performance Properties of Multi-Functional Finishes on the Enzyme-Pretreated Wool/Cotton Blend Fabrics
}

\author{
L. Ammayappan ${ }^{1 \dagger}$, J. Jeyakodi Moses ${ }^{2}$, K. Asok Senthil ${ }^{3}$, \\ A. S. M. Raja ${ }^{4}$ and Lam K. C. Jimmy \\ ${ }^{1}$ Mechanical Processing Division, National Institute of Research on Jute and Allied Fiber Technology, Kolkatta-700040, India \\ ${ }^{2}$ Department of Chemistry, PSG College of Technology, Coimbatore-641004, India \\ ${ }^{3}$ Clariant Chemicals (India) Ltd., Tirupur, India \\ ${ }^{4}$ Division of Textile Manufacture and Textile Chemistry, Central Sheep and Wool Research Institute, Avikanagar-304501, India \\ ${ }^{5}$ Institute of Textiles and Clothing, The Hong Kong Polytechnic College, Hong Kong
}

(Received: January 24, 2011/Revised: February 28, 2011/Accepted: March 3, 2011)

\begin{abstract}
Research information related to application of enzyme as pretreatment and subsequent functional finishing on wool blended textiles for imparting multi-functional properties is still scanty. Yarn-blended wool/cotton fabric was pretreated with both a cellulase (Bactosol-CA) or a protease (Savinase-16.0LEx) in individual, subsequently finished with SynthappretBAP and $\beta$-cyclodextrin based combination to impart anti-shrink, anti-microbial, softening and anti-crease properties. The performance of the finished fabrics depended on type of finishing combinations applied rather than enzyme pretreatment. Savinase pretreatment followed by Synthappret+Ceraperm-MW combination finishing impart both anti-shrink property as well as softening, while Bactosol pretreatment followed by $\beta$-cyclodextrin and sanitize combination finishing impart antimicrobial activity as well as anti-shrink finish to the wool/cotton blend fabric.
\end{abstract}

Keywords: wool, cotton, blend fabric, cellulase, protease, finishing

\section{Introduction}

Blending is one of the value-adding steps in textiles since two distinct fibers are mixed for the development of newer product.

Polyester and cotton fiber are preferred to be blended from $10 \%$ to $90 \%$ with other textile fibers in order to improve the durable and handle value of the blended textiles. Blended textiles from wool and cotton have many pleasing features, like warmth, good moisture absorption and soft handle ${ }^{1)}$. Central Sheep and Wool Research Institute in India, a premium research institute for wool research, had developed a blend fabric from cotton warp and wool weft that satisfies the desirable properties of winter shawl ${ }^{2}$. Chemical processing such as preparatory process, dyeing and finishing plays an important role in the textile market. Since each processing improves the aesthetic property of textiles as well as functional properties and so it can satisfy wide range of customers as per their needs ${ }^{3)}$. Wool, a unique natural fiber, has scales on its surface with hydrophobic nature, which has drawbacks in chemical processing ${ }^{4)}$.

Pre-treatment such as chlorination, plasma treatment, enzyme treatment etc., is preferred to improve the physio-chemical as well as functional properties of woolen textiles ${ }^{5-7)}$.

Research information on finishing of wool/ cotton blended textiles was available mainly for specific functional finishes like flame-retardant finish, anti-shrink finish and anti-crease finish. Vinyl phosphonate oligomer was applied to cotton/ wool blended twill fabrics by a pad-dry-cure process to impart flame-retardant finish ${ }^{8)}$.

Dry wrinkle recovery of wool/cotton fabrics was improved by the treatment with dimethyloldihydroxy ethylene urea (DMDHEU) ${ }^{9)}$.

The presence of wool in untreated wool/cotton twill fabrics caused burning rates to decrease and

${ }^{\dagger}$ Corresponding author. Tel.: +91-3324711807; Fax.: +91-3324712583; e-mail: lammayappan@yahoo.co.in

(c)2011 The Korean Society of Dyers and Finishers 1229-0033/2011-3/1-10 
oxygen index values to increase as wool content increased in the blends ${ }^{10)}$. A mixture of a DMDHEU and the Synthappret BAP by a simple pad-dry-cure procedure on wool/cotton blend improve wrinkle recovery ${ }^{11)}$. Wool/cotton blend (50/50) treated with mixed emulsion containing DMDHEU and $2 \%$ aziridinyl-adeprene L-100 polymer gave permanent press effects ${ }^{12}$. DMDHEU based polymer finishing on cotton-wool (60/40) blends gave durable-press finishing ${ }^{13)}$. Intimate blend of unchlorinated wool and cotton attained higher resistance to pilling when finished with soft acrylic resins combined with dimethyl siloxane, synthetic wax, glyoxal and melamine resin $^{14)}$. Fluorocarbon based finishing on wool blended fabrics imparted soil resistance finish, since it reduces surface free energy of both fibres ${ }^{15)}$.

Literature on application of both enzyme pretreatment and functional finishing on wool blended textiles for imparting multi-functional properties was still scanty.

A study was conducted on wool/cotton blend fabric, which was pretreated with a cellulase and a protease separately, subsequently finished with Synthappret- BAP and $\beta$-cyclodextrin combination in order to impart anti-shrink, anti-microbial, softening and anti-crease properties.

\section{Material and Methods}

\subsection{Materials}

\subsubsection{Wool/cotton blend fabric}

Wool/cotton blend fabric of following specification was taken for this study : 40 ends per inch, 15 picks per inch, $2 / 2$ twill weave, $340 \mathrm{~g} / \mathrm{m}^{2}, 1.50$ mm thickness, 2/15's warp, $2.75 \mathrm{Nm}$ weft and a blend ratio of wool to cotton is 67:33.

\subsubsection{Enzymes}

The details of different enzymes used for this study were given in Table 1. Based on the composition of wool/cotton in the blend fabric and on manufacturer's technical information, the concentration of enzymes used for this blend fabric was optimized as $1 \mathrm{~g} / \mathrm{L}$ of Bactosol-CA Liq. and $2 \%$ of Savinase-16.0LEx on the weight of blend fabric (owb).

\subsubsection{Finishing chemicals}

The finishing chemicals used for this study were supplied by Clariant Chemicals (India) Ltd., Mumbai, India.

They were Finish-VLF (F-VLF, modified $N$ methylol dihydroxylethylene urea), Ceraperm-MW (C-MW, modified micro polysiloxane), SandopermRPU (S-RPU, Polyurethane based softener), SandosoftSPG (S-SPG, Cationic softener), Ceraperm-UP (C-UP, modified macro polysiloxane), Sanitized T-9919 (S-9919, Cationic quaternary ammonium silicone based antimicrobial agent) and Sandoclean-PCJ (S-PCJ, non-ionic wetting agent). Synthappret BAP (S-BAP, bisulphate adducts of polyurethane) was supplied by LANXESS India Pvt. Ltd., Mumbai. $\beta-$ Cyclodextrin $(\beta-C D)$ was supplied by DKSH India Pvt. Ltd., Mumbai. All other chemicals used in the study were AR grade.

\subsection{Methods}

\subsubsection{Enzyme treatments}

The cellulase was applied on blend fabric using the following condition: $1 \mathrm{~g} / \mathrm{L}$ enzyme, liquor ratio of $1: 10, \mathrm{pH}$ of 5.0 (adjusted with addition of 0.5 $\mathrm{mL} / \mathrm{L}$ acetic acid solution) at $50^{\circ} \mathrm{C}$ for 60 minutes. The protease was applied using the following condition: $2 \%$ enzyme (over the weight of wool portion), 1:10 liquor ratio and $\mathrm{pH}$ 8.5(adjusted

Table 1. Details of the enzymes used

\begin{tabular}{lll}
\hline Enzyme & EC No & Source \\
\hline Savinase-16.0LEx & E.C.3.4.21.62 (alkali stable protease) & Novozymes South Asia Pvt. Ltd., India \\
\hline Bactosol-CA & Acid stable cellulase & Clariant Chemicals (I) Ltd., Mumbai, India \\
\hline
\end{tabular}


with addition of $0.5 \mathrm{~g} / \mathrm{L}$ sodium carbonate solution) at $55^{\circ} \mathrm{C}$ for 60 minutes.

After each enzyme treatments the fabric was washed, rinsed well, dried at ambient condition.

\subsubsection{Finishing treatments}

The recipe for five different finishing formulations was given in Table 2.

For S-BAP based finishing, the required amount of S-BAP was taken along with S-RPU/C-MW.

It was mixed with $0.25 \mathrm{~g} / \mathrm{L}$ Sandoclean-PCJ solution and stirred well. The dissolved sodium bicarbonate solution was then added gradually with constant stirring and the $\mathrm{pH}$ was adjusted to $7.8 \pm 0.2$. Blend fabric of $35 \mathrm{~cm} \times 35 \mathrm{~cm}$ dimension was immersed in the finishing bath at $25^{\circ} \mathrm{C}$ for 5 minutes and padded with $80 \%$ wet pickup under $1.5 \mathrm{~kg} / \mathrm{cm}^{2}$ using a laboratory padder (RB Engineering Ltd., Gujarat, India). After padding, the fabric was dried at $100^{\circ} \mathrm{C}$ in an oven and cured at $160^{\circ} \mathrm{C}$ for 5 minutes in high temperature steamer (RB Engineering Ltd., Gujarat, India), conditioned for 48 hours, washed with distilled water and dried.

Table 2. Finishing formulations

\begin{tabular}{|c|c|c|}
\hline Recipe (g/L) & & Abbreviation \\
\hline Unfinished & & Unfinished (F0) \\
\hline Synthappret-BAP & $=45$ & S-BAP \\
\hline $\mathrm{NaHCO}_{3}$ & $=4.5$ & $(\mathrm{~F} 1)$ \\
\hline Synthappret-BAP & $=30$ & \\
\hline Sandoperm-RPU & $=30$ & S-BAP+S-RPU \\
\hline $\mathrm{NaHCO}_{3}$ & $=3$ & \\
\hline Synthappret-BAP & $=30$ & \\
\hline Ceraperm-MW & $=60$ & 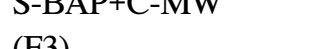 \\
\hline $\mathrm{NaHCO}_{3}$ & $=3$ & \\
\hline$\beta$-Cyclodextrin & $=16$ & \\
\hline Finish-VLF & $=60$ & \\
\hline Ceraperm-MW & $=30$ & $\mathrm{~F}-\mathrm{VLF}+\beta-\mathrm{CD}$ \\
\hline Ceraperm-UP & $=20$ & $(\mathrm{~F} 4)$ \\
\hline Sandosoft-SPG & $=30$ & \\
\hline $\mathrm{MgCl}_{2}$ & $=6$ & \\
\hline$\beta$-Cyclodextrin & $=16$ & \\
\hline Sanitized T-9919 & $=4$ & \\
\hline Finish-VLF & $=60$ & \\
\hline Ceraperm-MW & $=30$ & $\mathrm{~F}-\mathrm{V} \mathrm{LF}+\beta-\mathrm{CD}+\mathrm{S}-9919$ \\
\hline Ceraperm-UP & $=20$ & \\
\hline Sandosoft-SPG & $=30$ & \\
\hline $\mathrm{MgCl}_{2}$ & $=6$ & \\
\hline
\end{tabular}

For $\beta$-CD based finishing, the required amount of $\beta$-CD was taken and dissolved with gradual addition of $0.5 \mathrm{~g} / \mathrm{L}$ acetic acid solution and $0.25 \mathrm{~g} / \mathrm{L}$ Sandoclean-PCJ solution in a high speed stirrer with $\mathrm{pH}$ ranged from 4.8 to 5.0. After a clear solution was obtained, the other chemicals such as F-VLF/ S-9919 were added one by one with constant stirring and then the dissolved $\mathrm{MgCl}_{2}$ solution was added. The $\mathrm{pH}$ of the finishing solution was adjusted to 5.0 with $0.5 \mathrm{~g} / \mathrm{L}$ acetic acid solution. Blend fabric of $35 \mathrm{~cm} \times 35 \mathrm{~cm}$ dimension was impregnated in the finishing bath at $25^{\circ} \mathrm{C}$ for 5 minutes and padded with $80 \%$ wet pick up under $1.5 \mathrm{~kg} / \mathrm{cm}^{2}$ in a laboratory padding mangle. The padded fabrics were dried at $100^{\circ} \mathrm{C}$ in an air oven followed by curing in high temperature steamer at $150^{\circ} \mathrm{C}$ for 5 minutes, washed with distilled water and dried.

\subsection{Evaluation of performance properties}

The finished and unfinished fabrics with and without prior enzyme treatments were conditioned under standard condition $\left(20 \pm 2^{\circ} \mathrm{C}, 65 \pm 2 \%\right.$ Relative Humidity, 4 hours) and the following performance properties were evaluated as per established standards: dry crease recovery angle ${ }^{16}$, antimicrobial activity ${ }^{17)}$, area shrinkage ${ }^{18)}$, wicking height ${ }^{19)}$, tearing strength ${ }^{20}$, primary and total hand value for winter suiting fabric by Kawabata hand evaluation system for winter suiting fabric ${ }^{21}$, and bending length ${ }^{22)}$. For surface study, the unfinished and S-BAP-treated wool samples were examined with a JEOL scanning electron microscope (JSM 6360).

\section{Results and Discussion}

Wool/cotton blend fabric was pretreated with a cellulase and a protease separately followed by finishing with five different finishing combinations; their performance properties have been evaluated and discussed below.

\subsection{Finish add-on}

The percentage of finish added on the untreated and enzyme-treated wool/cotton blend fabrics are given in Fig. 1. 


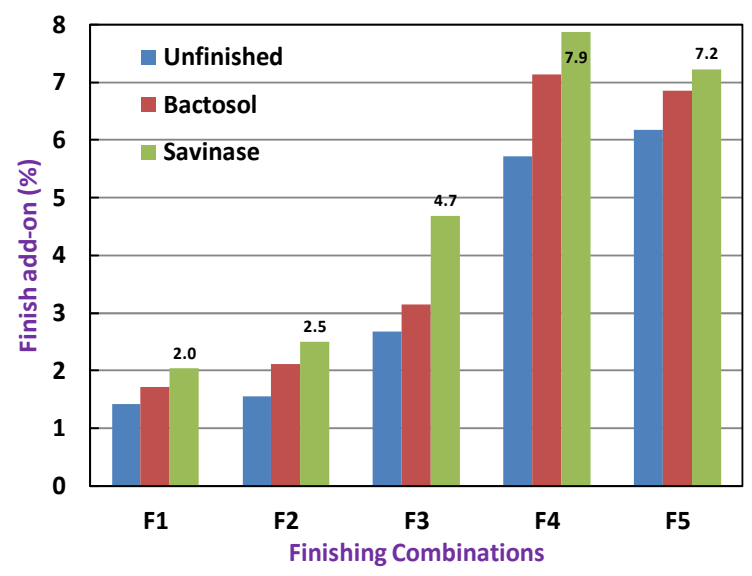

Fig. 1. Finish added on untreated and enzymetreated wool/cotton blend fabrics.

The weight loss due to cellulase and protease enzyme treatments was 1.51 and $4.66 \%$ respectively. It is observed that the finish add-on is higher in $\beta$-CD based finish than S-BAP based finish, since more finishing chemicals were taken $(150 \mathrm{~g} / \mathrm{L})$ in that formulation than others (60 to $90 \mathrm{~g} / \mathrm{L}$ ). Overall the mean of finish add-on is higher in Savinase treated fabrics (47\%) followed by Bactosol treated fabrics (22\%) than untreated fabric. It is also inferred that the amount of finish added to blended textiles could be depended on the modifications of its component fibers.

\subsection{Wicking height}

The wicking height of finished and unfinished wool/cotton blend fabric with and without prior enzyme treatment is given in Fig. 2.

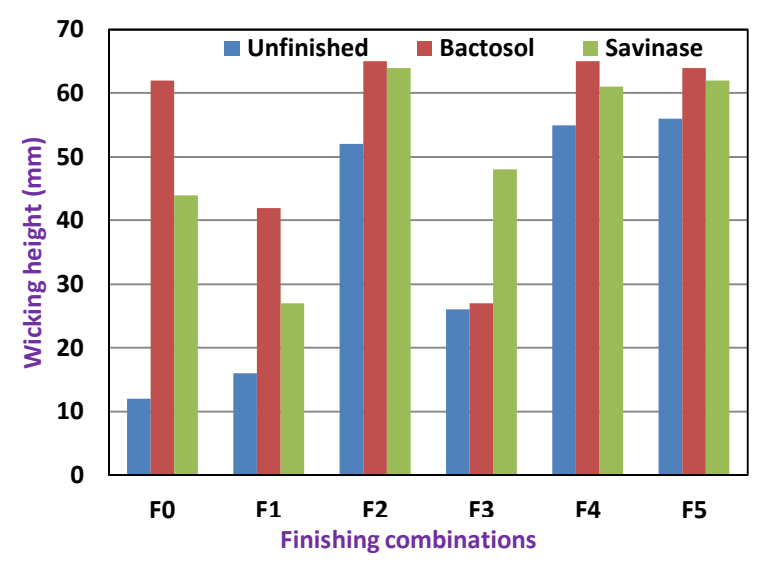

2a. Warp direction
It is noted that, the wicking of moisture is better in warp direction than weft direction after enzyme treatments and finishing. The proteasetreated and cellulase-treated fabrics are wicked more moisture than untreated fabrics after finishing. Among the finished fabrics, enzyme-treated and S-RPU finished fabrics are wicked more moisture than the other finished-only fabrics both in warp and weft directions. S-RPU is a polyurethane based polymer and it enriches with free hydroxyl groups. That free hydroxyl groups are capable of forming $\mathrm{H}$-bonding with water molecules easily and so it wicks more moisture than other finishing formulations.

\subsection{Tearing strength}

The tearing strength retention of finished and unfinished wool/cotton blend fabric with and without prior enzyme treatment is given in Fig. 3.

The tearing strength of the blend fabric after enzyme treatments is reduced both in warp and weft directions. Generally enzyme modifies the fibre both in surface as well as morphological aspects, which breaks chemical bonding in amorphous and crystalline regions of polymer chain in some extent. This causes a reduction in tensile strength of textiles. The S-BAP based finishing retained the tearing strength of enzyme treated fabric in weft direction, while it is slightly improved in warp direction.

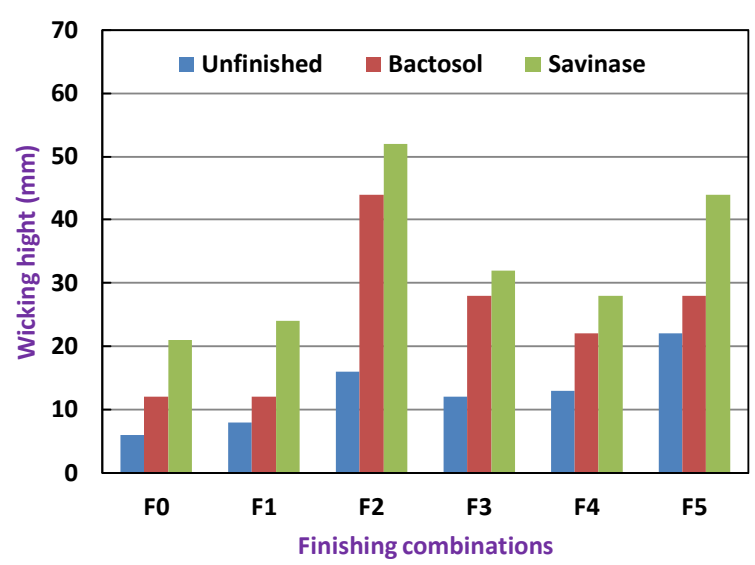

2b. Weft direction

Fig. 2. Wicking height of finished and unfinished wool/cotton blend fabrics. 


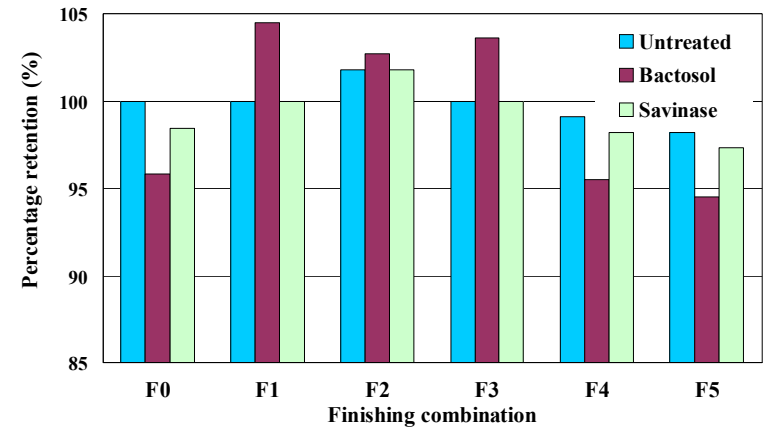

3a. Warp direction

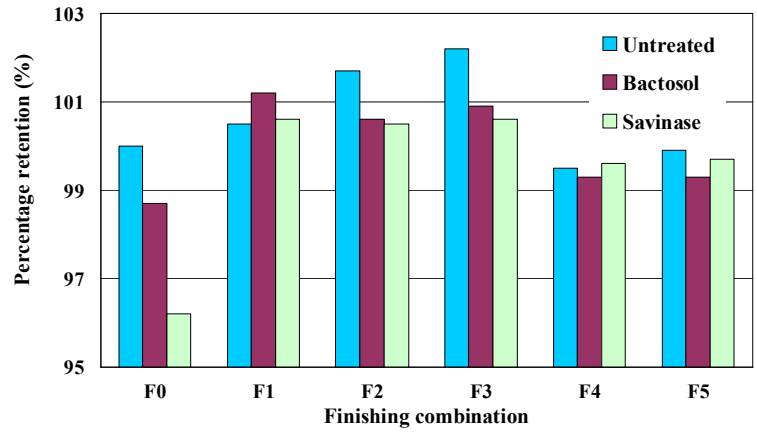

3b. Weft direction

Fig. 3. Retention of tearing strength of finished and unfinished wool/cotton blend fabrics.

However F-VLF based finishing is reduced the tearing strength ofthe untreated as well as enzyme treated fabric and the percentage reduction is higher in warp direction (5\%) than weft direction $(2 \%)$. It is also observed that, the mean of percentage reduction of tearing strength of finished fabrics is higher in cellulase-treated than corresponding proteasetreated ones.

S-BAP diffuses into wool fiber due to the preferential sorption of the polymer by the nonkeratinous region present in ortho cortex, while it may spread on the surface of cotton fibre. During heat curing, the polymer causes crosslinking between polymer and reactive groups in the wool and reactive hydroxyl groups of cotton fibre. This crosslinking could be expected to reinforce the intercellular region of both fibers ${ }^{23,24)}$. The subsequent encapsulation of surface modified wool and cotton fibers by the S-BAP combination finishing combination is the reason for the regain of tearing strength to higher value. Generally F-VLF based combination on natural fibre reduces the strength of fibre due to crosslinking occurring in acidic $\mathrm{pH}$ that breaks intermolecular bonding of fibre particularly in cotton fibre. So the tearing strength F4 and F5 finished fabrics are lower than other finished fabrics.

\subsection{Shrinkage}

The total shrinkage due to relaxation, consolidation and felting of finished and unfinished wool/cotton blend fabric with and without prior enzyme treatment is given in Fig. 4. Wool fibre is easily susceptible to shrink during home

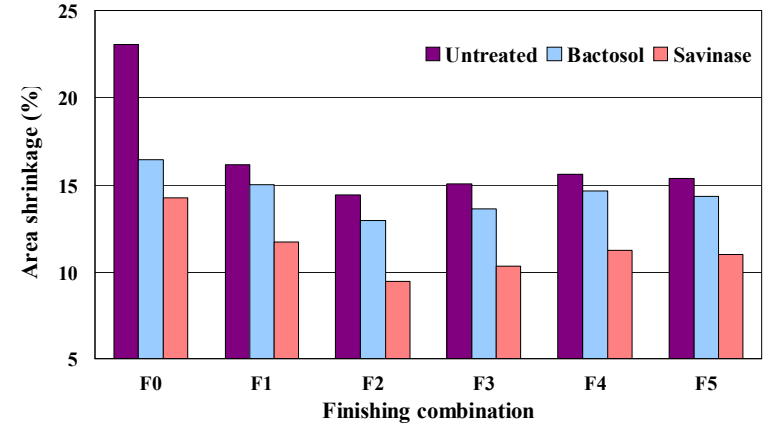

Fig. 4. Shrinkage of finished and unfinished wool/ cotton blend fabrics.

laundering in comparable to cotton due to presence of cuticle. Since wool portion is higher $(65 \%)$ than cotton portion $(35 \%)$ in this blend fabric, wool fibre plays a major role in the shrinkage of this blend fabric. The protease is modified the cuticle scales and alternatively reduced the felting shrinkage of the wool fiber. The encapsulation of modified fibre surfaces by the finishing formulations can further reduce the shrinkage of the blend fabric.

So the shrinkage of protease and finished fabrics (9.4 to $11.7 \%$ ) are lower than corresponding cellulase and finished ones (12 to 15\%). The protease-treated and S-BAP+S-RPU combination finished fabric (9.44\%) is shrunk lesser than other combination finished fabrics (> 10.34\%). The deposition of S-BAP polymer on the modified cuticle layer followed by masking the scales of the wool fibers and improvement in hydrophilicity by S-RPU polymer may reduce synergistically the differential friction effect of the wool fibers and alternatively reduces the shrinkage this blend fabric ${ }^{25,26)}$. 


\subsection{Objective assessment by KES-F}

The primary hand value in terms of smoothness (Numeri), stiffness (Koshi) and fullness (Fukurami) and total hand value (THV) for winter suiting fabric evaluated from these parameters are given in Fig. 5 and 6 respectively.

It is observed that, the primary hand value of the untreated fabric had very low smoothness (0.7), high stiffness (6.6) and medium fullness (3.8). The smoothness and fullness are improved with simultaneous reduction in stiffness after both enzyme treatment and also in subsequent finishing treatment. The protease-treated fabrics are showed better improvement in softness and fullness than cellulase-treated ones, before and after finishing. However the S-BAP and S-BAP+S-RPU based finishing on the enzyme treated fabrics reduce the smoothness and fullness since S-BAP polymer film has roughness feel $^{27)}$.

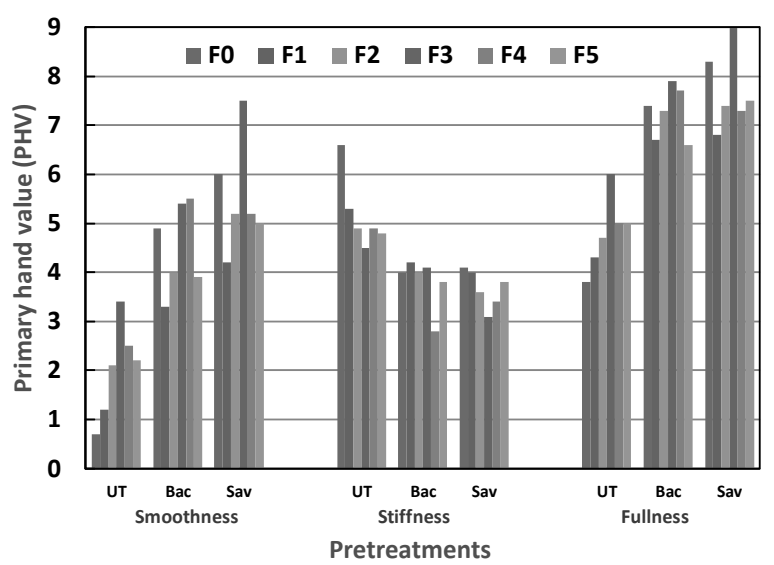

Fig. 5. Primary hand value of finished and unfinished wool/cotton blend fabrics.

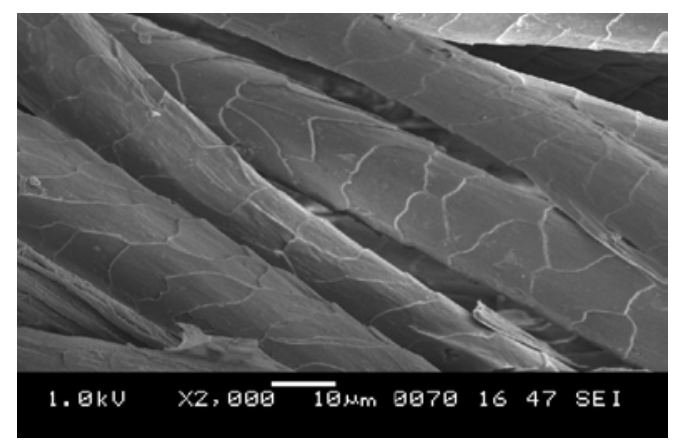

Protease-treated
However the other finishing formulations are shown either improvement or preserving the smoothness and fullness of the fabric.

The S-BAP+C-MW finished samples are shown higher primary hand values than other finished samples irrespective of pretreatment since generally microsilicone emulsion improves the softness and drape-ability of finished fabrics.

The protease- treated fabrics with and without finishing are showed better THV than their corresponding B-CA treated ones. The maximum THV is observed in protease-treated and S-BAP+ C-MW (3.7) combination finished fabric.

The formation of a uniform S-BAP polymer film on the enzyme modified surface of the wool fiber is evidenced from scanning electron microscope photographs as given in Fig. 7.

The S-BAP crosslinks with wool fiber and forms substituted urea ${ }^{28)}$. This stiff polymer coating on the surface of the blend fabric reduces the smoothness as well as total hand value.

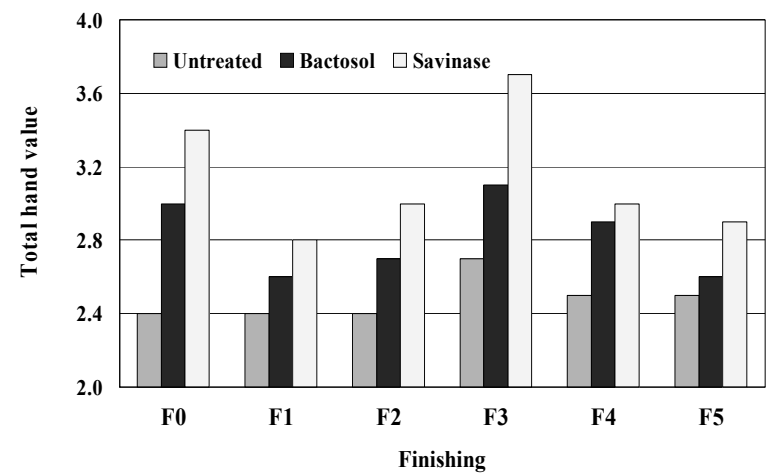

Fig. 6. Total hand value of finished and unfinished wool/cotton blend fabrics.

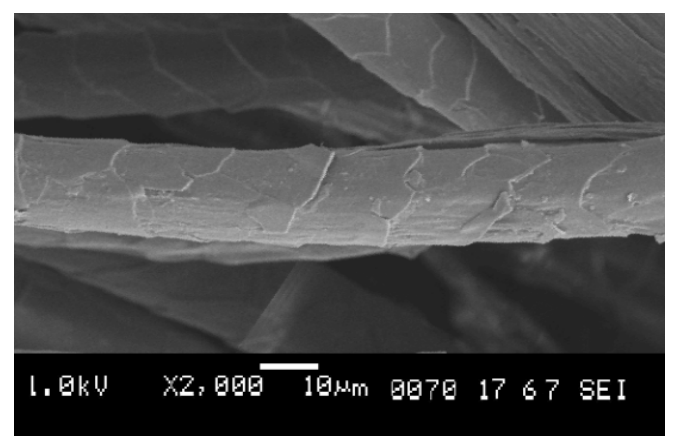

Protease-treated and S-BAP finished

Fig. 7. SEM photographs of protease-treated and S-BAP finished wool fiber. 


\subsection{Bending length}

The bending lengths of finished and unfinished wool/cotton blend fabric with and without prior enzyme treatment in warp and weft direction are given in Fig. 8.

It is observed that the bending length of untreated fabric is reduced significantly after these two enzyme treatment both in warp (from 16.9 to $14.3 \mathrm{~mm}$ ) and weft (from 18.8 to $14.2 \mathrm{~mm}$ ) directions. The bending length of blend fabric is in order of unfinished fabrics > finished-only fabrics > enzyme treated+finished. It is also noted that, S-BAP finishing increases the bending rigidity of fabric when applied alone, while the incorporation of either S-RPU or C-MW in the finishing formulation decreases significantly in warp and weft direction by. S-BAP polymer has the ability to form of inter-fiber bonds and hence it limits the relative movements of fibers when the fabric is deformed, resulting in an increase in fabric bending rigidity ${ }^{29)}$.

\subsection{Dry crease recovery angle}

The dry crease recovery angle of warp and weft direction is considered as total dry recovery angle (DCRA). The DCRA of finished and unfinished wool/cotton blend fabrics with and without prior enzyme treatment is given in Fig. 9.

The DCRA of untreated fabric is lower in warp direction $\left(100^{\circ}\right)$ than weft direction $\left(138^{\circ}\right)$.

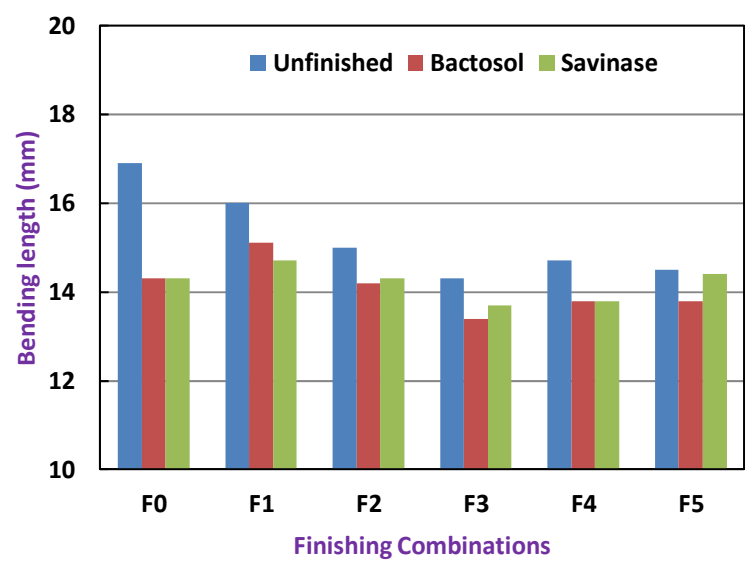

8a. Warp direction
It is slightly improved after each enzymatic treatment, which further improved both in warp and weft directions after finishing treatment. Overall, the total DCRA of enzyme treated and finished fabrics $\left(>255^{\circ}\right)$ are slightly higher than corresponding finished only fabrics $\left(<254^{\circ}\right)$. After finishing, the total DCRA is better in cellulase-treated fabrics (3.5\%) than corresponding protease-treated ones (1.9\%), when compared with the finish-only fabrics.

S-BAP based fabrics are shown higher DCRA in weft direction than warp direction and vice versa in F-VLF based finished fabrics. The F-VLF is a modified DMDHEU based crosslinking agent. It acts largely by making both wool and cotton fibers more resilient in which it thus increases their ability to recover from deformation. However S-BAP based finishing improves crease recovery by decreasing the frictional component of creasing, probably through the formation of elastic interfiber and inter-yarn bonds ${ }^{30-32}$.

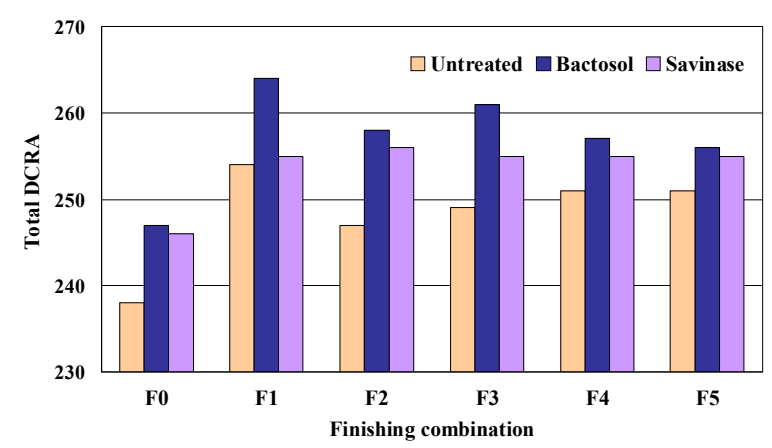

Fig. 9. Total dry crease recovery angle of wool/cotton blend fabrics.

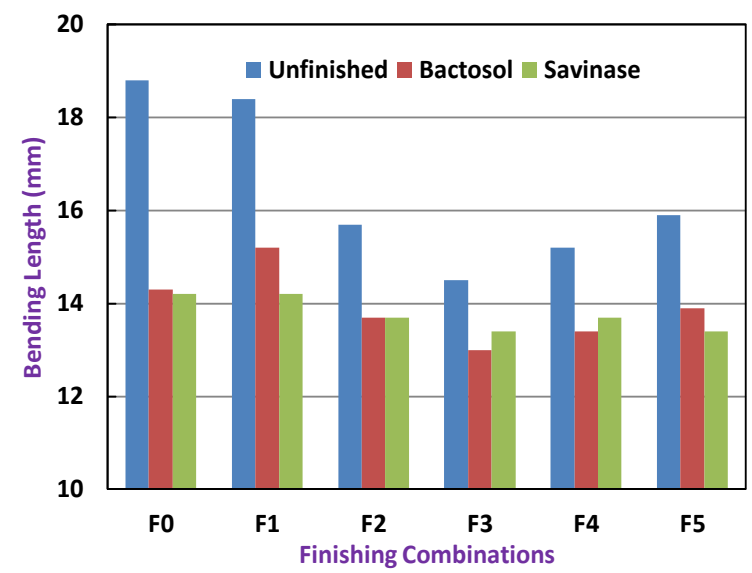

8 b. Weft direction

Fig. 8. Bending length of finished and unfinished wool/cotton blend fabrics. 


\subsection{Antimicrobial activity}

The zone of inhibition of gram-positive and gram-negative microorganisms on $\beta$-CD finished and unfinished wool/cotton fabric with and without prior enzyme treatment is given in Table 3 . It is observed thatz, the $\beta$-CD finishing is inhibited the bacterial (S-Aureus) growth on unfinished and enzyme treated fabric, while the zone of inhibition is better in cellulase-treated and $\beta$-CD finished fabric $(1.5 \mathrm{~mm})$ than their corresponding proteasetreated ones $(0.5 \mathrm{~mm})$.

The zone of inhibition is further improved by the addition of Sanitized-9919, an antimicrobial agent used in the market. The maximum zone of inhibition against S-Aureus is observed in cellulase-treated and $\beta$-CD+F-VLF+S-9919 treated fabric $(6.0 \mathrm{~mm})$, which inferred that S-9919 resists the bacterial growth in this combination. These two combination finishing do not resist the fungal growth in this fabric even after enzyme treatments.

\section{Conclusion}

The cellulase/protease pretreatment on wool/ cotton blend fabric modifythe respective component fibres. The polyurethane/modified DMDHEU based finishing combination encapsulates the enzyme treated fibres and that encapsulation improves their performance properties. The performance properties of protease treated fabrics are better than cellulase treated ones, since the proportion of wool fibre is higher than cotton portion in this blend fabric.

Table 3. Zone of inhibition of wool/cotton blend fabrics

\begin{tabular}{lcccc}
\hline \multirow{2}{*}{ Micro organism } & \multirow{2}{*}{ Finishing formulation } & \multicolumn{3}{c}{ Zone of inhibition(mm) } \\
\cline { 2 - 5 } S. Aureus & F0 & Untreated & Cellulase & Protease \\
\cline { 2 - 5 } & F4 & $0^{*}$ & 0.5 & No \\
\cline { 2 - 5 } & F5 & $0 *$ & 6.5 & 0.5 \\
\hline \multirow{3}{*}{ E. Coli } & F0 & No & No & No \\
\cline { 2 - 5 } & F4 & No & No & No \\
\hline & F5 & $0 *$ & No & $0 *$ \\
\hline
\end{tabular}

$0^{*}$ : No growth was observed underneath the fabric scratch

No: No zone of inhibition 
2. Anon, "Annual Report 2005-2006", CSWRI, Avikanagar, India, pp.54-56, 2006.

3. W. Ingamells, "Colour for Textiles-A User's Handbook", Society of Dyers and Colorists, UK, pp.1-16, 1993.

4. M. Lewin and S. B. Sello, "Handbook of Fiber Science and Technology", Volume-II, Part-B, Marcel Dekker, New York, pp.34-40, 1984.

5. K. Chi-wai, C. Kwong, and M. Y. Chun-wah, The Possibility of Low-Temperature Plasma Treated Wool Fabric for Industrial Use, AUTEX Research Journal, 4(1), 37-44(2004).

6. E. C. Hanekom, An Improved Process for the Chlorination of Wool with DCCA, SAWTRI Bulletin, 8(2), 19-21(1974).

7. A. Riva, J. Cegarra, and R. Prieto, The Role of an Enzyme in Reducing Wool Shrinkage, Journal of Society for Dyers and Colorists, 109(5/6), 210-213(1993).

8. J. V. Beninate, B. J. Trask, and G. L. Drake, Durable Flame-Retardant Treatments for Blends of Cotton, Wool, and Polyester, Textile Research Journal, 51(4), 217-224(1981).

9. C. E. Pardo, R. A. O’Connell and W. Fang, Wool/cotton Durable Presses Fabrics, American Dyestuff Reporter, 57, 894-897(1968).

10. J. V. Beninate, B. J. Trask, T. A. Calamari, and G. L. Drake, Wool: Its Effect on Flame Retardant Properties of Blend Fabrics, Journal of Fire Sciences, 1(2), 145-154(1983).

11. J. A. Rippon, Improving the Wrinkle Recovery of Wool/Cotton Blends by Simultaneous Treatment with Synthappret BAP and DMDHEU, Textile Research Journal, 57(11), 655-660(1987).

12. W. L. Wasley and A. G. Pitman, Aziridine Terminated Polyurethanes for Wool Finishing, Applied Polymer Symposium, 18(1), 537-543(1971).

13. R. J. Harper and P. Metha, Finishing CottonWool Blends, Textile Research Journal, 55(12), 761-766(1985).

14. J. M. Cardamone, Efforts to Control Pilling in Wool/Cotton Fabric, Textile Chemist and Colorist, 31(6), 27-30(1999).

15. R. H. Stephan, High Quality Soil Resistance
Finishing of Wool and Wool Blends, Textilveredlung, 32(7), 161-163(1997).

16. AATCC, AATCC Test Method 66-2003: Wrinkle Recovery of Woven Fabrics: Recovery Angle, "Technical Manual of the AATCC", Research Triangle Park, USA, 2003.

17. AATCC, AATCC Test Method 147-1998: Antibacterial Activity of Assessment of Textile Materials: Parallel Streak Method, "Technical Manual of the AATCC", Research Triangle Park, USA, 2003.

18. AATCC, AATCC Test Method 99-2000: Dimensional Changes of Woven or Knitted Wool Textile: Relaxation, Consolidation and Felting, "Technical Manual of the AATCC", Research Triangle Park, USA, 2003.

19. P. R. Harnett and P. H. Mehta, A Survey and Comparison of Laboratory Test Methods for Measuring Wicking, Textile Research Journal, 54(7), 471-478(1984).

20. ASTM, ASTM Test Method D 1424: Standard Test Method for Tearing Strength of Fabrics by Falling-pendulum Type (Elmendorf) Apparatus, "Annual Book of ASTM Standards: 07.01", West Conshohocken, PA, USA, 2004.

21. S. Kawabata, "The Standardization and Analysis of Hand Evaluation", 2nd edition, Textile Machinery Society of Japan, Osaka, 1980.

22. BSI, BS 3356:1990 - Test Method for Determination of Bending Length and Flexural Rigidity, "BS Handbook 11”, London, 1990.

23. J. R. Cook and B. E. Fleischfresser, Sorption of Water Soluble Anionic Polymer by Wool, Journal of Society for Dyers and Colorists, 54, 441-446(1984).

24. G. B. Guise and M. B. Jackson, The Shrink Proofing of Wool with the Bisulphite Adduct of Polyisocyanate, Journal of the Textile Institute, 64(3), 665-667(1973).

25. H. Ito, Y. Muraoka, R. Umehara, Y. Shibata, and T. Miyamoto, Shrink Resist Properties and Surface Characteristics of Wool Fibers Treated with Multifunctional Epoxides, Textile Research Journal, 64(8), 440-444(1994).

26. S. J. Moon and T. J. Kang, Effects of Epoxide 
| 10 | L. Ammayappan ·J. Jeyakodi Moses · K. Asok Senthil · A. S. M. Raja - Lam K. C. Jimmy

and Silicone Polymers on the Mechanical and Performance Properties of Wool Fabric, Textile Research Journal, 70(12), 1063-1069(2000).

27. K. M. Byrne, W. Bourn, M. Clark, and P. A. Duffield, "Zero AOX Garment Dyeing", Proceeding of $9^{\text {th }}$ International Wool Textile Conference, Vol. 1, p.191, 1995.

28. J. R. Cook, B. E. Fleischfresser, J. D. Leeder and J. A. Rippon, Sorption of SynthappretBAP by Wool and Its Effect on Abrasion Resistance, Textile Research Journal, 59(12), 154-157(1989).
29. W. S. Simpson and G. Crawshaw, "Wool: Science and Technology", Woodhead Publication Ltd., Cambridge, UK, pp.1-45, 2005.

30. E. F. Denby, The Wrinkle Resistance of Wool Fabrics Treated with External Polymers, Journal of the Textile Institute, 65, 660-661(1974).

31. R. Steele, Some Fabric Properties and Their Relation to Crease-Proofing Effects, Journal of the Textile Institute, 53, 7-21(1962).

32. J. A. Rippon, Effect of Synthappret-BAP on the Wrinkle Recovery of Uncrosslinked and Crosslinked Cotton, Textile Research Journal, 55(4), 239-247(1985). 